\title{
Felsötesti koordináció és a nyomásközponti trajektóriák regisztrálása kerekesszékben izomdystrophias betegekben
}

\section{Recording Trajectory of Upper-Body Coordination and Pressure Centre Points in Wheelchair Patients with Muscle Dystrophy}

\author{
Medveczky Erika1, Szalay Piroska², Nyakas Csaba³ ${ }^{3}$ Bretz Károly ${ }^{4}$ \\ 1 Szent János Kórház, Gyermekgyógyászati Rehabilitációs Osztály, Budapest \\ 2 Testnevelési Egyetem, Egészségtudományi és Sportorvosi Tanszék, Budapest \\ 3 Testnevelési Egyetem, Sport- és Természettudományi Kutató Központ, Budapest \\ 4 Testnevelési Egyetem, Biomechanikai Tanszék, Budapest
}

\begin{abstract}
Absztrakt: Jelen tanulmány célja az egyensúlyi és felsótesti koordinációs paraméterek meghatározása, a nyomásközépponti trajektóriák folyamatos regisztrálása kerekesszékben, a Duchenne (DMD) és Becker (BMD) izomdystrophiás, járóképességüket elvesztett fiúgyermekeknél. Tíz, progresszív lefolyású, neurológiai kórképben szenvedő fiú vett részt a mérésekben. Eróméró platformot, 1000 × 1000 mm-es mérőfelülettel, háromcsatornás erősítőt, mikroszámítógépet és laptopot tartalmazó mérörendszert alkalmaztunk. A koordinációs tesztek kiegészítésére „Psycho 8” választásos reakció-időmérőt és Dyna 10 univerzális erőmérőt használtunk,. Mért adatainkból látható, hogy a törzsizomzat viszonylagos érintetlensége, a piramis rendszer és az extrapiramidális rendszer múködésének pontossága, következésképpen a felsótesti koordináció megbízhatósága, valamint a vártnál kisebb látenciák tették lehetóvé azt, hogy a kerekesszékes vizsgálati csoport eredményei a gyermekek állásban mért koordinációs teljesítményeivel összemérhetónek, vagy annál jobbnak mutatkoztak.
\end{abstract}

Kulcsszavak: izomdystrophia, egyensúlytartás, stabilometria, felsótesti koordináció, kerekesszék

\begin{abstract}
The aim of the present study is the investigation of balance and upper body coordination parameters, continuous recording of the centre of pressure trajectories in wheelchairs, on boys suffering from Duchenne (DMD) and Becker (BMD) muscle dystrophy and have lost their walking ability. Ten boys suffering from progressive, neurological diseases participated in the measurements. The measuring system contained a force platform with a surface of $1000 \times 1000 \mathrm{~mm}$, a three-channel amplifier, a micro computer and a laptop. To complete the coordination tests a "Psycho 8" choice reaction time measurement device and a Dyna 10 type dynamometer were used. Our data show that the trunk muscles are relatively untouched, the accuracy of functioning of the pyramid and the extra pyramidal system, consequently the reliability of the upper body coordination, as well as the lower than expected latencies made it possible that the results of the wheelchair study group were comparable (or even better) to the coordination performance of children in standing position.
\end{abstract}

Keywords: muscle dystrophy, balance, stabilometry, upper body coordination, wheelchair

\section{Bevezetés}

Az izomsorvadásos betegségek nagy terhet jelentenek az egyénre és a társadalomra egyaránt. Két jól ismert betegség, a Duchenne izomdystrophia
(DMD) és Becker izomdystrophia (BMD) (MD: muscle dystrophy). A Duchenne-féle izomdystrophia az izomsejtek fokozatos pusztulásával járó, veleszületett, örökletes betegség. Az 
izomsejtek helyét az izommunkára képtelen zsírszövet és kötőszövet tölti ki, ebből adódóan a beteg egyre erőtlenebb lesz, míg végül önmaga ellátása is gondot jelent (17). A betegség tulajdonképpeni oka a dystrophin nevü fehérje kóros képződése, illetve hiánya $(11,12,13)$. Emiatt kalcium ionok áramlanak be az izomsejtek közé korlátlan mennyiségben, így azok pusztulását idézik elő.

A Becker féle izomdystróphiában szenvedő betegek elsősorban fiúk, tünetei hasonlók, a betegség azonban kevésbé súlyos. A progresszív lefolyású izomsorvadással élő betegek funkcionális állapotának objektív mérési adatok alapján való megállapítása igen fontos.

Ez egy, non-invazív vizsgálattal lehetséges, mely stabilometriát alkalmaz. Ez a neuromuszkuláris rendszer szintjén szolgáltat adatokat, melyek tájékoztatásul szolgálhatnak a komplex rehabilitáció eredményességének megítélése tekintetében $(1,7,9)$. Remélhető, hogy az ezen adatok ismeretében folytatott rehabilitáció is hozzájárulhat az életminőség minél jobb és hosszabb távon történő megtartásához $(14,15,16)$.

Vizsgálataink célja, hogy két, különböző korú Duchenne (DMD) és Becker (BMD) izomdystrophiás fiú csoportban meghatározzuk az egyensúlyi és felsőtesti koordinációs paramétereket, a nyomás-középponti trajektóriák folyamatos regisztrálásával.

Az egyik csoportot 10 éves fiúk képezték, akik még nem vesztették el járóképességüket. A másik csoportot 13 éves fiúk alkották, akik már elvesztették járóképességüket, ezért kerekesszéket használtak. Feltételeztük, hogy a fiatalabb betegcsoport egyensúlyi és felsőtesti koordinációs paraméterei jobbak, mivel a betegség még kezdetibb stádiumban van.

\section{Módszerek}

A szülők jelenlétében, tíz, progresszív lefolyású, neurológiai kórképben szenvedő fiú vett részt a mérésekben. A vizsgált gyermekek átlagos életkora: 10,9 $\pm 3,93$ év. A kerekesszékkel közlekedők átlagos életkora: 13,67 \pm 4,62 év.

Erőmérő platformot, 1000 x 1000 mm-es mérőfelülettel, háromcsatornás erősítőt,

ADDON mikroszámítógépet és laptopot tartalmazó mérörendszert alkalmaztunk $(2,3,4,5)$. A berendezést a Feed 103C szoftver müködtette (Ing. Büro, Bretz). „Psycho 8” választásos reakció-időmérőt és Dyna 10 univerzális erőmérőt használtunk a koordinációs tesztek kiegészítésére $(4,6,8)$.

Az 1. ábra a választásos reakció-időmérő adapterét mutatja be. A fényingereket zöld, valamint piros színű, világító diódák közvetítik. Zöld fény esetén a „válasz” nyomógomb megnyomásával válaszolni kell. A válasz elmulasztása az „A” hiba. Piros fény esetén a gomb megnyomása hibának minősül („B” hiba).

A 2. ábra a reakció-időmérést mutatja be. A gyermek pozíciója a kerekesszékes egyensúly- és koordinációmérésnél alkalmazott helyzettel megegyezik. A kerekesszék a növelt felületű erőmérő platformon („stabilométeren”) nyert elhelyezést.

A 3. és a 4. ábrán a vizsgált gyermek ülve szimulálja a Romberg I. és II. pozíciót (nyitott, illetve csukott szemmel). Az egyensúlyi stabilitás mérési ideje 20 s. A nyomásközépponti elmozdulások időfüggvényeit és spektrumát regisztráljuk (5. ábra).

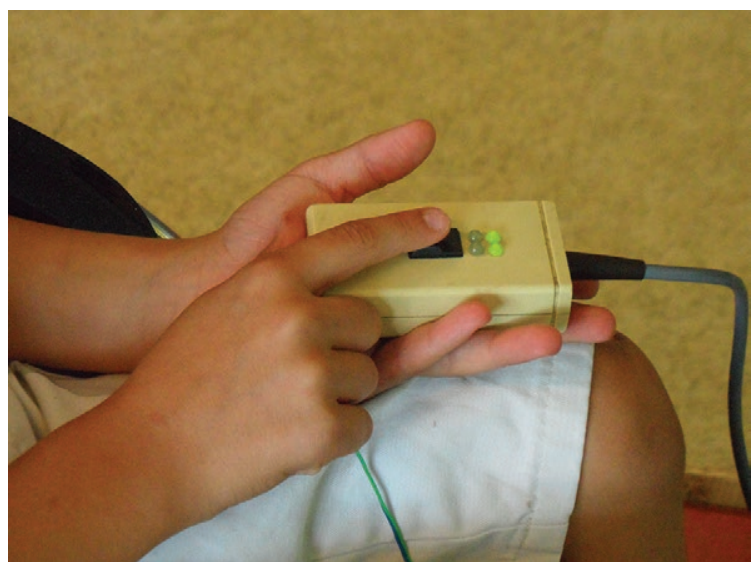

1. ábra: A választásos reakcióidő mérőberendezés kezelő adaptere [Forrás: saját szerkesztés]

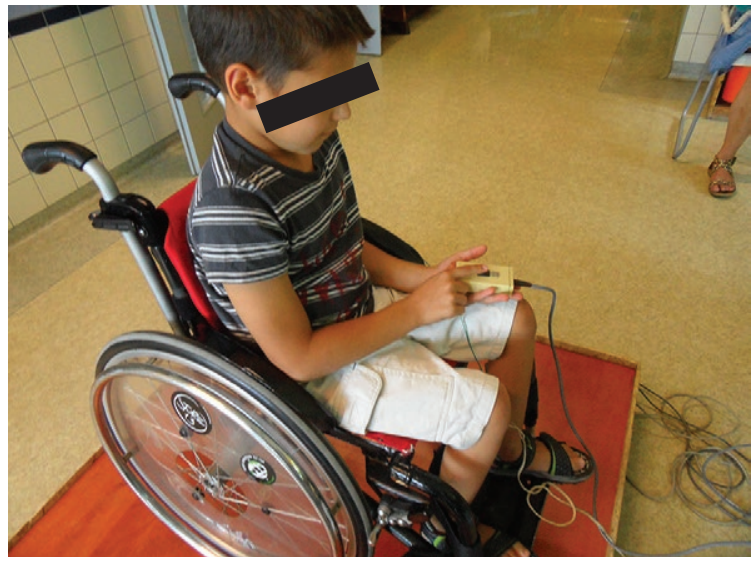

2. ábra: A reakcióidő mérése [Forrás: saját szerkesztés] 


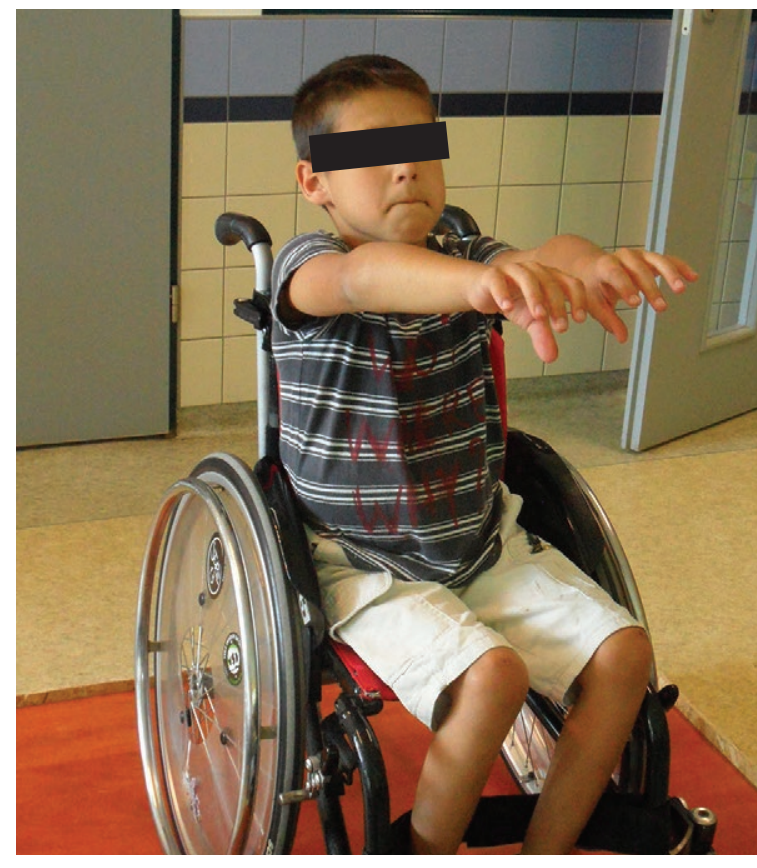

3. ábra: Romberg $<$ RI > teszt [Forrás: saját szerkesztés]
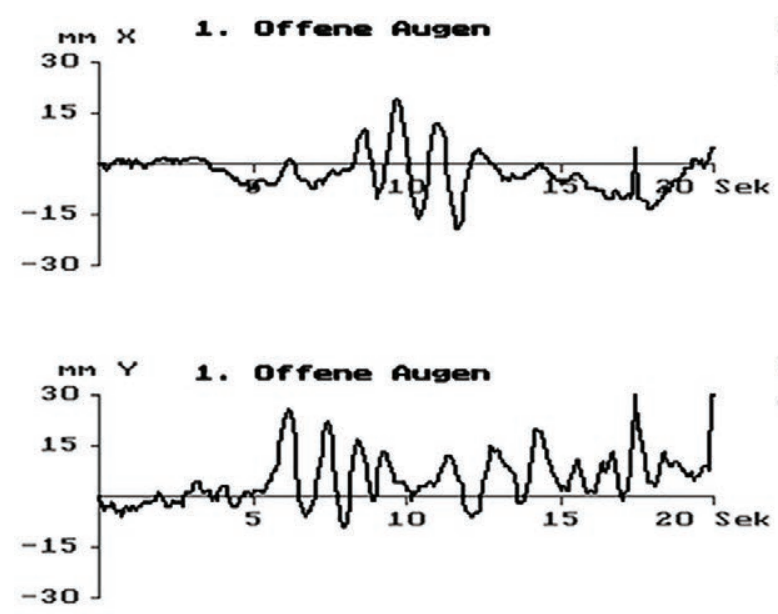

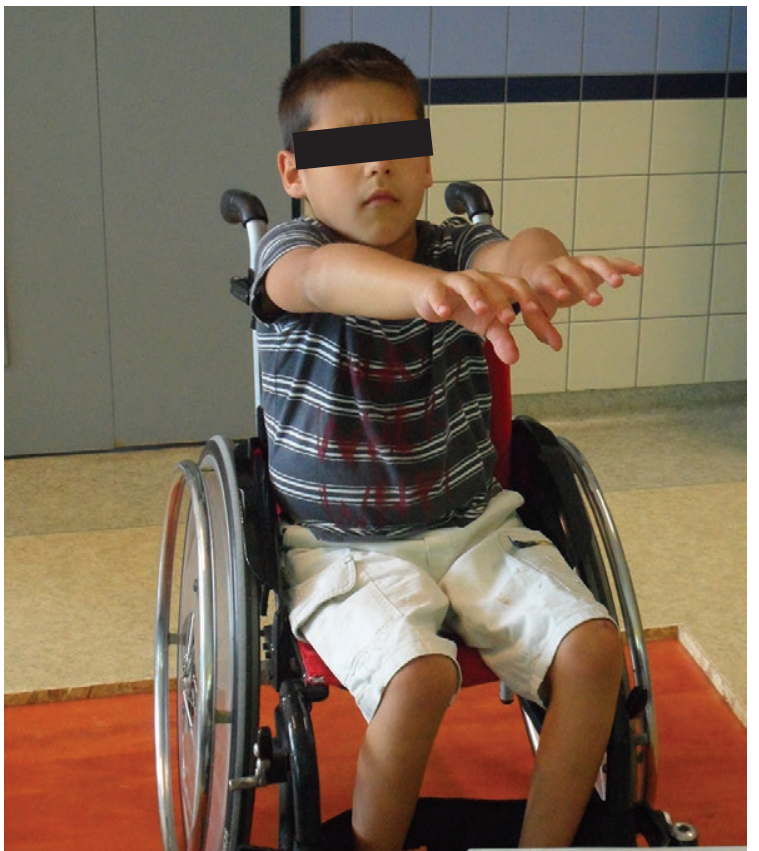

4. ábra: Romberg < RII > teszt [Forrás: saját szerkesztés]
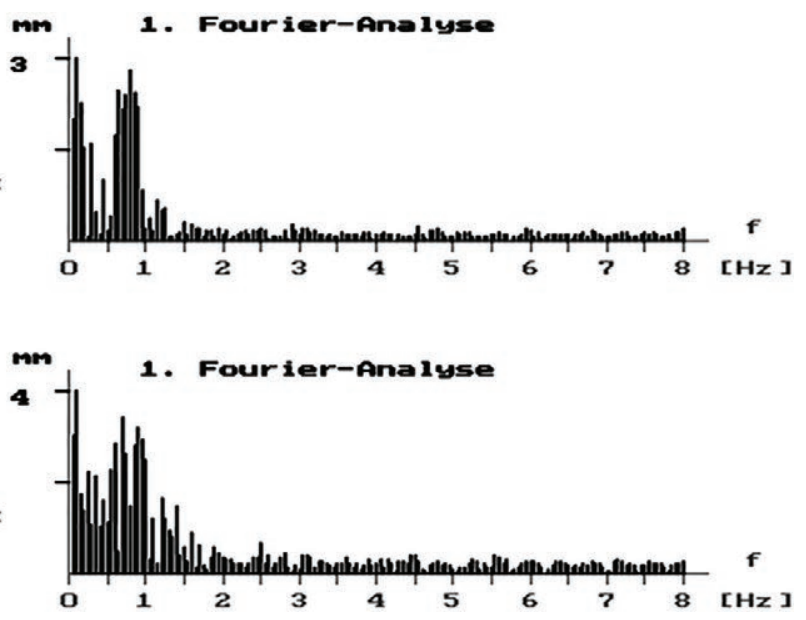

5. ábra. Stabilogramok, eredeti regisztrátumok: $\mathrm{x}(\mathrm{t})$ : oldalirányú lengések időfüggvénye és frekvencia spektruma, $\mathrm{y}(\mathrm{t})$ : előre-hátra irányuló lengések időfüggvénye és frekvencia spektruma [Forrás: saját szerkesztés]

A vizsgáltok során a pozíció szabályozás stabilitását mértük (18). A vizsgálat húsz másodpercig tartott. A képernyőn lévő négyzetet a szálkereszten kellett tartani. Az értékelésnél a 100\% volt a maximális teljesítmény (6. és 7. ábra).

\section{„Karácsonyfa”: követö szabályozási teszt}

Feladat: a nyomásközéppont mozgatása 6 definiált pozícióba. Az egésztest (kerekesszékben a felsőtest) koordinációjával, megfelelő irányú döntésével, a platformra értelmezett egyenlő szárú háromszögben lévő, a monitoron látható hat kijelölt pontot kellett elérni a nyomásközépponttal. Az értékelés alapja a teljesítés ideje: másodperc $(\mathrm{s})(\mathrm{K})$ (8. ábra).

\section{„Mouse” követöszabályozási teszt}

A platform középponthoz képest aszimmetrikusan elhelyezett pontot kellett az egérrel szimulált kurzorral visszajelzett nyomásközépponttal elérni (9. ábra). Az értékelés alapja a teljesítés ideje: másodperc (s) (M). 


\section{„Festés": pozíciószabályozási teszt}

Feladat: a tömegközéppont mozgatása egy definiált felületen belül, melynek mérete $70 \times 70 \mathrm{~mm}$ $(19,20)$. A platformra értelmezett 70 x 70 mm-es négyzetet kellett a nyomásközépponttal, az egésztest kismérvű mozgatásával, illetve kerekesszékben a felsőtest koordinációjával bejárni (befesteni). A vizuális feed-back információ a monitoron volt látható. Az értékelésnél két adatot regisztráltunk: a felület befestésének mértékét \%-ban („siker”) és a kijelölt négyzeten belüli tartózkodást, a 20 másodperces teszt idő \%-ában (10. ábra).

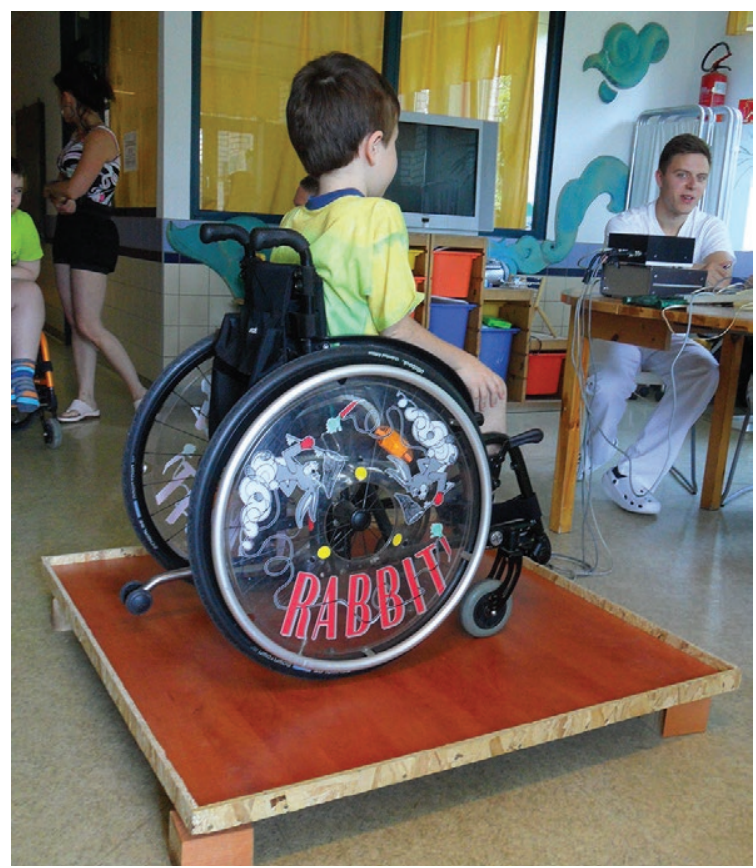

6. ábra: „Centrum” pozíciószabályozási teszt vizuális visszacsatolással. Hibajelzés: $\pm 15 \mathrm{~mm}$ pozícióvesztés esetén [Forrás: saját szerkesztés]

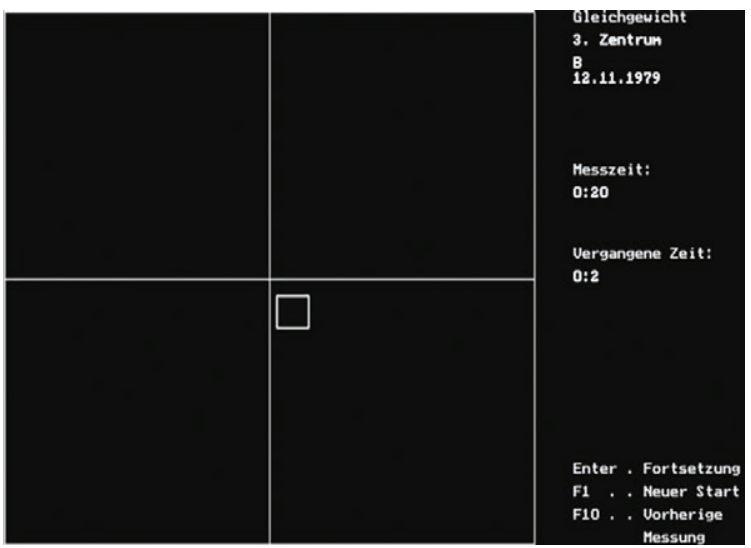

7. ábra: A szabályozás vezető jele a képernyőn [Forrás: saját szerkesztés]

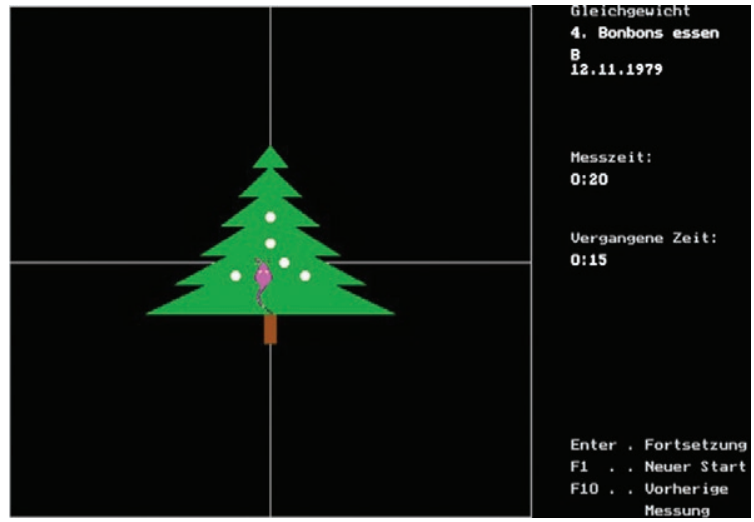

8. ábra: „Karácsonyfa” követő szabályozási teszt [Forrás: saját szerkesztés]

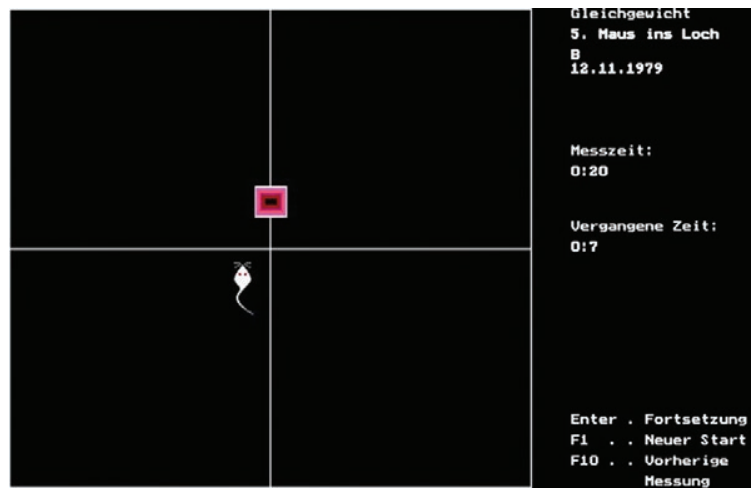

9. ábra: „Mouse” teszt illusztrálása [Forrás: saját szerkesztés]

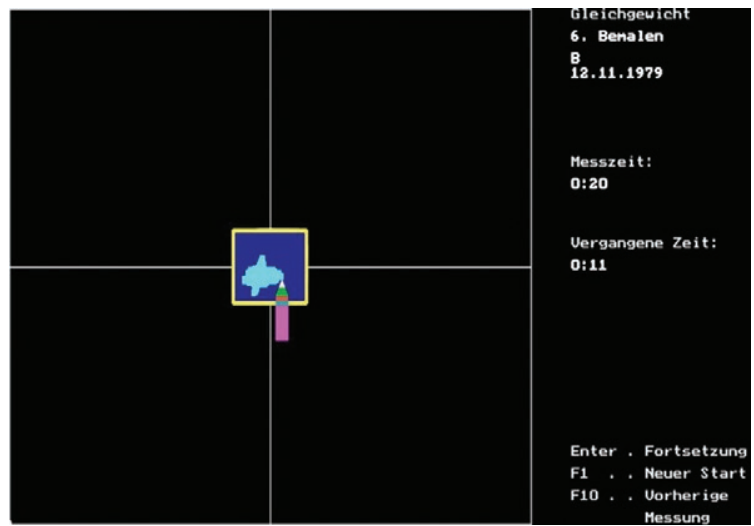

10. ábra: „Festés” teszt illusztrálása [Forrás: saját szerkesztés]

\section{Eredmények}

A tesztek elvégzése során a következő eredményeket kaptuk a két csoportban:

- A domináns kéz, szorító ereje teszt:

- 10 évesek: $\mathrm{F}=80,2 \pm 42,54 \mathrm{~N}$

- 13 évesek: $F=56,67 \pm 6,11 \mathrm{~N}$ 
- Választásos reakcióidő tesz:

- 10 évesek: RT = 421,8 $\pm 110 \mathrm{~ms}$

- 13 évesek: $\mathrm{RT}=306 \pm 47 \mathrm{~ms}$

- Centrum teszt:

- 10 évesek: $\mathrm{C}=91,6 \pm 11 \%$

- 13 évesek: $\mathrm{C}=98,6 \pm 2,3 \%$

- Karácsonyfa teszt:

- 10 évesek: $K=12,4 \pm 5,6 \mathrm{~s}$

- 13 évesek: $K=10,33 \pm 8,39 \mathrm{~s}$

- Mouse teszt:

- 10 évesek: $M=4,9 \pm 2,5 \mathrm{~s}$

- 13 évesek: $M=3,33 \pm 1,5 \mathrm{~s}$

- Festés teszt (siker)

- 10 évesek: $F s=45,2 \pm 22,8 \%$

- 13 évesek: Fs $=50,33 \pm 2,9 \%$

$\mathrm{Az}$ „Eredmények” lényegének és jelentésének magyarázatait az „Anyag és módszerek” c. részben fejtettük ki.

\section{Megbeszélés}

A vizsgált, kis létszámú betegcsoportnál a kerekesszékkel közlekedők idősebbek voltak, mint a még járni képes betegcsoport, ezért az izomerő csökkenés következtében a felső végtagok izomereje, így a kezek szorítóereje kisebb, míg a választásos reakcióidejük rövidebb (jobb) volt.

A kerekesszékben ülőknél a pozícióstabilizálás és a koordináció is jobb eredményt mutatott. A betegség progressziója következtében azonban az alsóvégtagok érintettsége erőteljesen fokozott. Érdekes módon, ez a tény a kerekesszékben vizsgált felsőtesti koordináció eredményeiben kevésbé jutott kifejezésre. Azaz a várható adaptációt, ha van is, nem tudtuk mérni.

Tapasztalatunk szerint a törzsizomzat viszonylagos érintetlensége lehetővé tette, hogy a vizuális információkat közvetítő receptorok, a központi szabályozó mechanizmusok, a vártnál kisebb látencia idő, a piramis rendszer és az extrapiramidális rendszer működésének pontossága, következésképpen a felsőtesti koordináció eredményessége, a gyermekek állásban mért koordinációs teljesítményével összemérhető, vagy annál jobb is volt.

Jövőbeli vizsgálatainkban a jelenleg kapott eredményeinket az egészséges gyermekek kerekesszékben végzett koordinációs méréseivel kívánjuk öszszehasonlítani. Ezt Szabadszálláson, Bács-Kiskun Megye egyik legrégebbi városában a Petőfi Sándor általános Iskolában tesszük meg, mivel ebben az iskolában a betegség miatti hiányzások száma elhanyagolható.

\section{Következtetések}

Vizsgálataink elösegítik egy olyan objektív mérési rendszer kifejlesztését és gyakorlatba állítását, amivel a Duchenne és Becker (BMD) izomdystrophia betegségekben és egyéb izomsorvadásban szenvedők állapotát, ill. a rehabilitáció eredményességét meg tudjuk becsülni.

\section{Irodalom}

1. Anker, L.C., Weerdesteyn, V., van Nes, I.J.W., Nienhuis, B., Straatman, H. és Geurts, A.C.H. (2008): The relation between postural stability and weight distribution in healthy subjects. Gait and Posture, 27: 471-477. http://dx.doi. org/10.1016/j.gaitpost.2007.06.002

2. Aruin, A.S., Nicholas, J.J. és Latash, M.L. (1997): Anticipatory postural adjustments during standing in below the knee amputees. Clin. Biomech, 12: 52-59. http://dx.doi. org/10.1016/s0268-0033(96)00053-8

3. Balasubramaniam, R., Riley, M.A. és Turvey, M.T. (2000): Specificity of postural sway to the demands of special task. Gait and Posture, 11: 12-24. http://dx.doi.org/10.1016/ s0966-6362(99)00051-x

4. Bretz, K.J. (2005): A testlengés és a kéz tremor méréstechnikája. Hiradástechnika, 60(4): 18-21.

5. Bretz, K. (1997): The stability of the human body's equilibrium. Avtoreferat, VAK, Kiev. 1-50. (in Russian)

6. Bretz, K., Medveczky, E., Heintz, B., Bretz, K.J. és Nyakas, Cs. (2015): Komplex mérési metodika az állapotváltozás objektiv követésére gyermekkori neurológiai kórképekben. 12. Országos Sporttudományi Kongresszus. 24-25.

7. Bretz K., Medveczky E., Heintz B. és Bretz K.J. (2014): Neuromuszkuláris teljesitmények és artériás oxigén szaturáció a Duchenne-féle izomdystrophia esetén. 44. Mozgásbiológiai Konferencia, Budapest. 11-12.

8. Bretz, K.J. és Sipos, K. (2003): Tremor and stress during college examination. Kalokagathia, 41(1): 111-115.

9. Bretz, É., Kocsis, L. és Bretz, K. (2004) Balance investigation based on inverted pendulum 
model of standing human body. In Proc. of the 1st Hungarian Conference on Biomechanics, June 11-12. 43-49.

10. Mayer, A., Tihanyi, J., Bretz., K., Csende, Zs., Bretz, E. és Horváth, M. (2011): Adaptation to altered balance conditions in unilateral amputees due to atherosclerosis: a randomized controlled study. $B M C$ Musculoskeletal Disorders, 12: 118-125. http:// dx.doi.org/10.1186/1471-2474-12-118

11. Medveczky, E., Bretz, K.J., Heintz, B. és Bretz K. (2013): Izomerö és reakcióidö Duchenne-féle izomdystrophia esetén. 43. Mozgásbiológiai konferencia, Budapest, Semmelweis Egyetem TSK. 21-22.

12. Medveczky, E., Bretz, K.J. Heintz, B. és Bretz, K. (2015): Gyermekek izomerö, reakcióidó és kardiorespiratórikus paramétereinek vizsgálata cerebrális paresis esetén, selektiv dorsalis rhisotomia elött és után. 45. Mozgásbiológiai Konferencia, Budapest. 16-17.

13. Medveczky, E., Bretz, K.J. Heintz B. és Bretz K. (2015): Gyermekek izomerö, reakcióido" és kardiorespiratórikus paramétereinek vizsgálata cerebrális paresis esetén, selektiv dorsalis rhisotomia elótt és után. Színes sporttudomány. Tanulmányok a 45. Mozgásbiológiai Konferencia előadásaiból (szerk.: Borbély Attila, Hamar Pál, Kotányi Magdolna). 49-54.
14. Medveczky, E. (2015): Dinamikus medikális ortézis (DMO) a gyermekkori neurorehabilitációban. Rehabilitáció, 25(1-2): 53.

15. Medveczky, E. (2015): Dinamikus medikális ortézis (DMO) a neurorehabilitációban. Rehabilitáció, 25(3): 77-78.

16. Medveczky, E. (2015): Dinamikus Medikális Ortézis (DMO) a gyermekkori neurorehabilitációban. Orvosi Rehabilitáció ORFMMT Gyermekszekció, Budapest.

17. Medveczky, E., Heintz, B., Bretz, K.J., Nyakas, Cs. és Bretz, K. (2016): Izomerö, koordináció, kardiorespiratórikus paraméterek és választásos reakcióidö méréstechnikája gyermekkori neurológiai kórképekben. Rehabilitáció, 26(1): 207-210.

18. Nievergelt, J., Farrar, J.C. és Reingold, E.M. (1977): Matematikai problémák megoldásának számitógépes módszerei. Müszaki Könyvkiadó, Budapest.

19. Rougier, P.R. és Genthon, N. (2009): Dynamical assessment of weight-bearing symmetry during upright quiet stance in humans. Gait \& Posture, 29: 437-43. http:// dx.doi.org/10.1016/j.gaitpost.2008.11.001

20. Stépán, G. (1994): Balancing with reflex delay. Proceedings of the 12. Int. Symp. on Biomechanics in Sports, Budapest. 